\title{
変形性膝関節症に対する湿熱シートの効果について
}

\author{
瀬戸宏明*1 池田浩*1 久岡英彦*2 \\ 小田英志*3 石川修司*3 黒澤尚*1
}

\section{Effect of Heat and Steam Generating Sheets on Osteoarthritis of the Knee}

\author{
Hiroaki Seto, ${ }^{* 1}$ Hiroshi IKedA, ${ }^{* 1}$ Hidehiko Hisaoka, ${ }^{* 2}$ \\ Eishi Oda, ${ }^{* 3}$ Syuji IshiKawa, ${ }^{* 3}$ Hisashi KuRosawA ${ }^{* 1}$
}

\begin{abstract}
Objective : To evaluate the effect of heat and steam generating sheets on osteoarthritis of the knee. Methods : Subjects with osteoarthritis of the knee $(n=41)$ were randomized into 2 groups : a heat and steam generating sheet group or a heat generating sheet group. Functional impairment [Western Ontario and McMaster Universities Osteoarthritis Index (WOMAC) and Japan Orthopaedic Association score (JOA score) ] in the index knee were measured at baseline and then again after 2 and 4 weeks of wear. Results : At both the 2 and 4 week patient evaluations, the heat and steam generating sheet group showed improved total WOMAC scores. Although the heat generating sheet groups' WOMAC scores were improved after 2 weeks, the difference between the 2 and 4 week evaluations was not statistically significant. As for individual WOMAC scores, patients in the heat and steam generating sheet group especially demonstrated a highly significant decrease in WOMAC stiffness score. In comparison, patients in the heat generating sheet group showed no improvement in WOMAC stiffness score. Gait ability improvement, as measured by JOA score, showed similar results for both groups. Conclusion : This study showed that using heat and steam generating sheets decreased pain and stiffness, and increased gait ability in patients with osteoarthritis of the knee. (Jpn J Rehabil Med $2007 ; 44: 347-351$ )

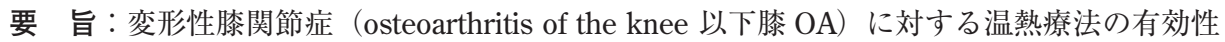
は広く知られているが一般的には乾熱によるものが大半である。今回は蒸気発生を伴う湿熱シ 一トを開発し，その効果について検討したので報告する。膝 OA と診断された女性 41 例のう ち 4 週間治療を継続し得た 37 例（湿熱シート群 20 例，乾熱群シート 17 例）を対象とした. 評価は，WOMAC，日整会膝 OA 評価点（JOA score）などを用いて，治療前，治療開始 2 お よび 4 週間後に行った。 total WOMACでは，湿熱群は 2 週後，4 週後ともに有意な改善がみ られた。乾熱群でも開始 2 週後には改善がみられたがその後は改善がみられなかった。 WOMAC の各項目のうち特に stiffness では湿熱群でのみ有意な改善がみられた. JOA score で も歩行能に関して湿熱群でのみ有意に改善がみられた. 以上より湿熱シートの効果は疼痛, 特 に歩行能やこわばり感の改善に対する有効性がより高いことが確認された.
\end{abstract}

Key words : 蒸気湿熱シート (heat and steam generating sheet), 変形性膝関節症（osteoarthritis of the knee)

2006 年 10 月 5 日受付, 2007 年 3 月 23 日受理

*1 順天堂大学医学部整形外科/ $=113-8431$ 東京都文京区本郷 2-1-1

Department of Orthopaedics, Juntendo University School of Medicine

* 2 順天堂大学医学部総合診療科/ $=113-8431$ 東京都文京区本郷 2-1-1

Department of General Medicine, Juntendo University School of Medicine

*3 花王株式会社ヘルスケア第 2 研究所/ $=131-8501$ 東京都墨田区文花 2-1-3

Kao Cooperation

E-mail : hseto@pop06.odn.ne.jp 


\section{はじめに}

運動器の疼痛において古来よりさまざまなリハビリ テーションが行われているが, 多くは物理療法が取り 入れられている.そのうちの1つにホットパックなど に代表される湿熱を利用した温熱療法が挙げられる. しかしこれらを施行するには通院が必要となるが社会 的, 地理的条件などから通院困難なことも少なくない と思われる，われわれは以前腰痛に対して PCH-SS と いう湿熱シートを開発して使用したところ良好な結果 が得られた ${ }^{1)}$. 関節症については Michlovitz らが湿熱 を手関節痛に使用して良好な結果を報告している2. しかし使用された形状は単純なものであり複雑な動き をする部位には適しているとは言い難く，可動域を制 限しないとあるが可動部位关のものに使用しているわ けではないため手関節以外の使用は厳しいと思われ る. よってその他の場所の関節症には臨床応用ができ るとはいいがたいものであった。

今回われわれは長時間使用可能で薄型・軽量でかさ ばらない体の動きに順応しやすい湿熱シートを開発し たので，変形性膝関節症（osteoarthritis of the knee：

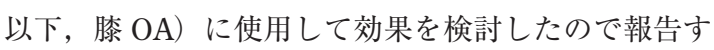
る.

\section{対象と方法}

今回の検討は順天堂大学医学部附属病院倫理委員会 の承認を得て実施された。事前にインフォームド・コ ンセントを行い，同意を得られた被験者のうち臨床診 断掞よび単純 X 線撮影より膝 OA と診断された女性 41 人 41 膝について乱数表を用いてランダムに 2 群に 分けて検討を行った。その内訳は湿熱シート群が 20 人, 乾熱シート群は 21 人 $(45 \sim 69$ 歳 $)$ であった.

湿熱㧍よび乾熱シートの発熱源はどちらも鉄粉が空 気中の酸素によって酸化される際に生ずる熱である. 鉄粉がパルプ紙に固定化された紙状の発熱体を用いて いるため, 薄型軽量でかつ柔軟性があり，広い面積を 均一に温める特長がある. 従って, 膝関節の動きにも 追随しやすい。湿熱シートはシート内部の発熱組成物 に含まれる水が，シートの発熱により皮膚適用面であ る透湿性のシート側から水蒸気となって発生する．湿 熱シートが熱と水蒸気を発生する原理は, 次の化学反 応式で示される.
$\mathrm{Fe}+3 / 4 \mathrm{O}_{2}+$ 過剩水 $\geqq \mathrm{Fe}(\mathrm{OH})_{3}+$ 反応熱 + 水蒸気

発生した水蒸気は, 皮膚表面で凝縮水となり, 潜熱 を放出するため，熱拡散による乾熱の伝熱に比べ伝熱 効率が高い。湿熱シートと乾熱シートは, 水蒸気が発 生する点を除き, 適用時の皮膚温度や形状等はすべて 同一のものとなるように設計し，予数名の健康成人 でシート直下の皮虐温が約 $40{ }^{\circ} \mathrm{C} て ゙ ， 5 \sim 8$ 時間持続 することを確認した。人体へ温熱を適用する場合に問 題とされる低温熱傷は, 皮膚温度とその温度での持続 時間に影響を受けることが知られているが ${ }^{3)}$ ，本試験 品の温度と今回の装着時間（6 時間以内）であれば安 全性は極めて高いと考えられた，両シートの 1 枚あた りの発熱面積は $54 \mathrm{~cm}^{2}$ であった。

各群の被験者には日中に, 1 日 1 回 6 時間を限度と して，それぞれのシートを使用した．左右のいずれか 片側の膝部に 2 枚を貼付し, その上から薄型の伸縮サ ポーターで固定し適用した。試用期間は 4 週間継続と し，その間は内服剤などの使用は一切行わなかった。 そして使用開始前後に評価を行い判定を行った。また シート貼布部位の皮膚所見も医師が確認して試験品使 用による有害事象発生の有無も確認した.

評価項目として日整会 OA 滕治療成績判定基準 (JOA score), WOMAC (Western Ontario and McMaster Universities OA Index), visual analogue scale （VAS）を使用した。

JOA score は疼痛・歩行能, 疼痛・階段昇降能, 関 節可動域，関節腫脹について評価するものである.

WOMAC は疾患特異型, 自己管理型の健康状態測 定法で股関節または膝関節の双方または一方の OA を 患っている患者の pain, stiffness, physical function disability の計 24 項目に自答式に記入し, 評価する方 法である4).

VAS は膝痛症状に対して痛みなしを $0 \mathrm{~mm}$, 想像で きうる最も強い痛みを $100 \mathrm{~mm}$ として評価した。

統計学的検討については湿熱, 乾熱シート群の 2 群 間の有意差検定には Student-t 検定を用いた。またX 線 stage については Mann-Whitney のU 検定を用い た。そして最後に各群の使用前, 使用後の統計処理に は paired t-testを用いた。

\section{結果}

4 週間継続終了後の脱落者は 4 名であった。 その内 
訳はアキレス腱断裂が 1 名, 貼布部位の皮膚炎が 1 名, 使用部位を逆にしたもの 1 名, 内服使用者が 1 名であ る. その結果, 湿熱シート群 20 膝, 乾熱シート群 17 膝となりこれらについて検討を行った. なお 2 群間の 年齢, BMI (body mass index), 各評価項目に有意差 は認められなかった（表)。

表 対象群

\begin{tabular}{lcc}
\hline & 湿熱群 $(n=20)$ & 乾熱群 $(n=17)$ \\
\hline 平均年齢 & 54.5 歳 & 56.0 歳 \\
& $(47 \sim 68$ 歳 $)$ & $(45 \sim 66$ 歳 $)$ \\
BMI & $24.3 \pm 5.4$ & $23.3 \pm 3.9$ \\
total WOMAC score & $26.9 \pm 16.1$ & $24.4 \pm 20.9$ \\
JOA score & $85.3 \pm 11.2$ & $86.5 \pm 9.3$ \\
VAS pain & $47.5 \pm 27.1$ & $36.8 \pm 26.2$ \\
$\quad$ こわばり & $47.1 \pm 30.8$ & $33.4 \pm 25.4$ \\
OA stage I & 5 & 2 \\
$\quad$ II & 14 & 12 \\
III & 1 & 2 \\
IV & 0 & 1 \\
\hline
\end{tabular}

\section{湿熱}

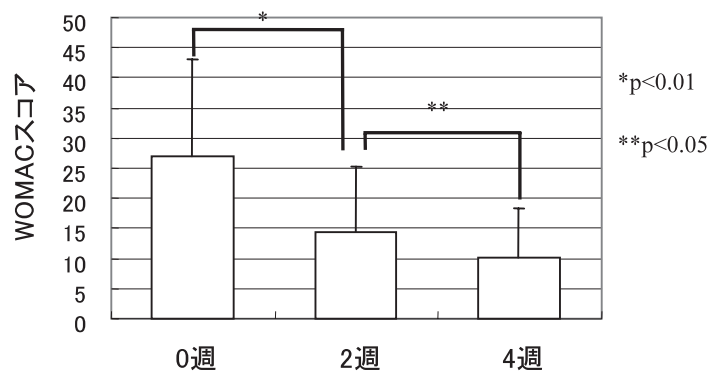

乾熱

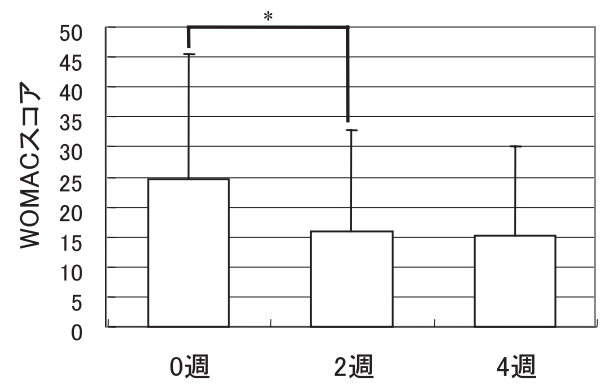

図 1 total WOMAC score における改善度

総合評価に扔いて蒸気湿熱群では 2 週から 4 週にかけて有 意なスコア改善がみられたが, 乾熱群では同時期に改善が みられなかった。
まず total WOMAC score であるが湿熱シート群にお いて使用開始前は $26.9 \pm 16.1$, 乾熱シート群で $24.6 \pm$ 20.9 であったが開始 4 週間後ではそれぞれ $10.2 \pm 8.0$, $15.1 \pm 15.1$ とおのおの有意に改善をしていた. しかし 経過をみていくと使用開始前より開始 2 週間後ではお のおの改善が認められているが, その後開始 4 週間後 まででは湿熱シート群でのみ $14.4 \pm 4.9$ より $10.2 \pm 8.0$ $(p<0.05)$ と有意な改善が認められていた（図 1). WOMAC の各項目であるが pain については両群間で 有意差は認められなかった。しかし stiffness では開始 2 週間後より開始 4 週間後で湿熱シート群は $1.6 \pm 1.4$ より $0.9 \pm 0.9(p<0.05)$ と有意に改善が認められてい るのに対して乾熱シート群では差が認められなかった (図 2). physical function disability では total WOMAC score や stiffness のように開始 2 週間後から開始 4 週 間後にかけての改善は認められなかった。しかし使用 開始前より開始 2 週間後で両群共に有意に改善が認め られた（湿熱シート群: $p=0.00017$, 乾熱シート群 : $p=0.01)$.

JOA score では使用開始前と開始 4 週間後で両群間

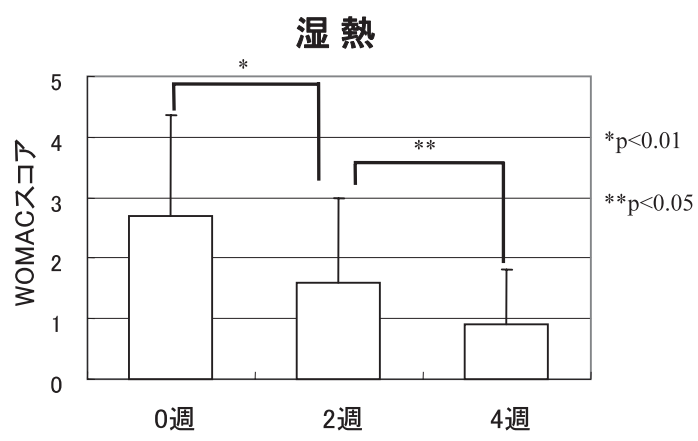

乾熱

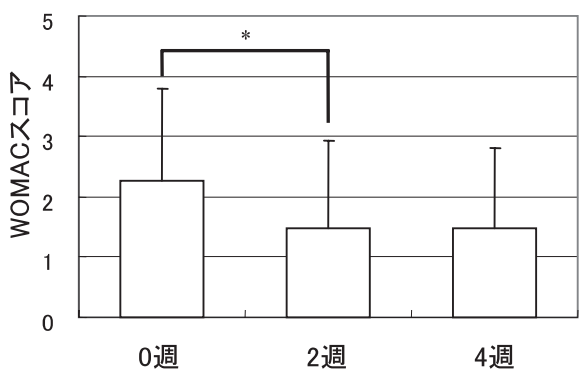

図 2 WOMAC stiffness score に扔ける改善度 総合評価と同様に蒸気湿熱群では 2 週から 4 週にかけて有 意なスコア改善がみられたが, 乾熱群ではやはり同時期に 改善がみられなかった。 

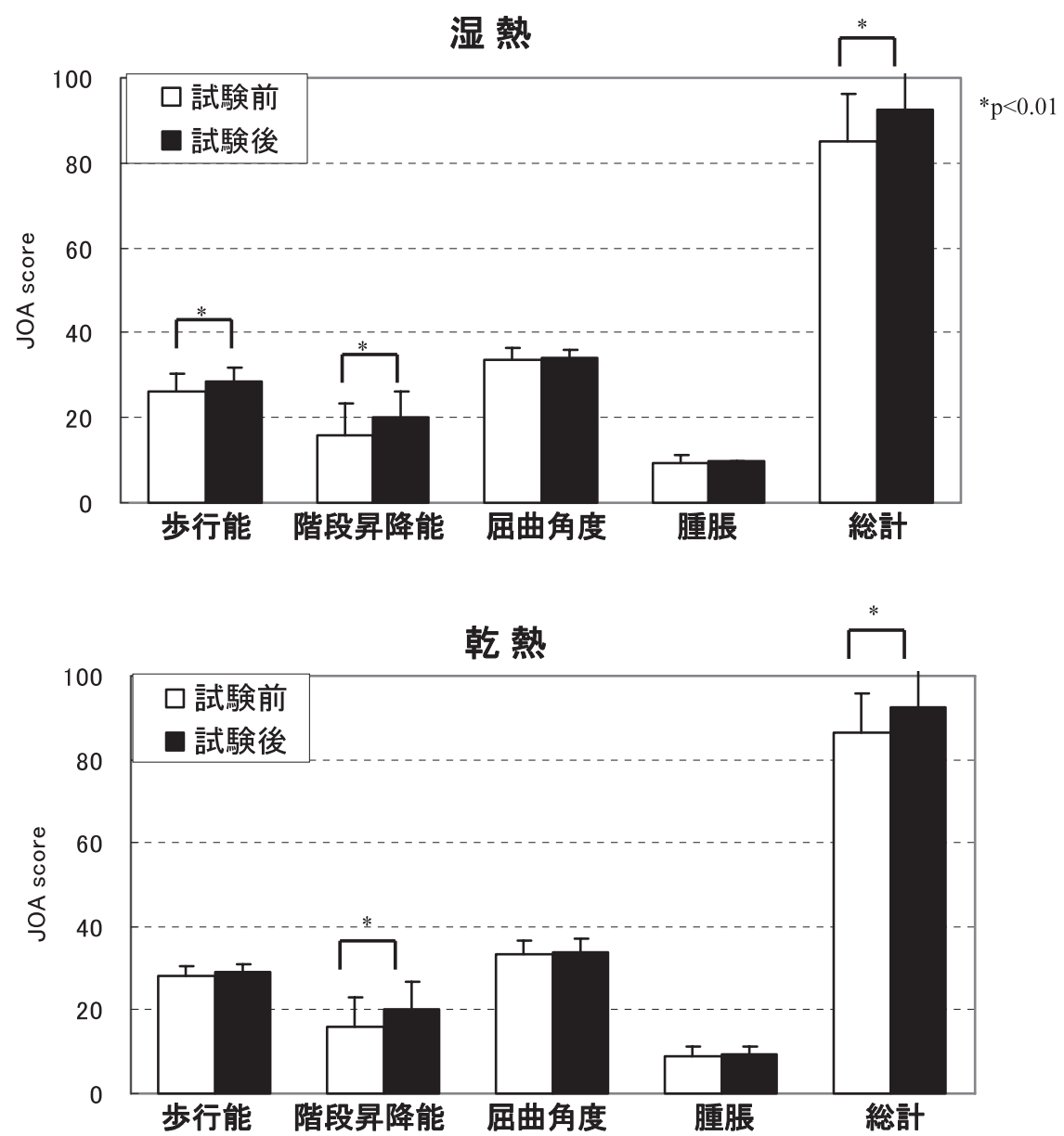

図 3 JOA score における改善度

総合評価では両群とも有意な改善がみられたが, 歩行能では湿熱群のみ有意な改善がみられた.

とも改善は認められていたが, 歩行能に関しては湿熱 シート群で $26.0 \pm 4.2$ より $28.5 \pm 3.3(p<0.01)$ である が乾熱シート群では $28.2 \pm 2.5 よ り 29.1 \pm 2.0$ (N.S) と改善は認められなかった（図 3).

VAS では痛みについては湿熱シート群で $47.5 \pm$ $27.1 \mathrm{~mm}$ が $18.0 \pm 18.9 \mathrm{~mm}$, 乾熱シート群で $36.8 \pm$ $26.2 \mathrm{~mm}$ が $17.2 \pm 19.1 \mathrm{~mm}$ と両群とも WOMAC pain 同様両群ともに有意差は認められたが両群間に有意差 は認められなかった。 またこわばりについては湿熱シ ート群が $47.1 \pm 30.8 \mathrm{~mm}$ より $15.1 \pm 18.1 \mathrm{~mm}$, 乾熱シ ート群で $33.4 \pm 25.4 \mathrm{~mm}, 14.9 \pm 19.0 \mathrm{~mm}$ であり, 両 群間を比較するとこれもWOMAC stiffness 同様湿熱 シート群で有意な改善が認められた。

有害事象については重篤なものはいなかった。投薬 が必要な皮膚炎が湿熱シート群, 乾熱シート群ともに
1 名ずついたが途中で中止せざるをえなかったのは乾 熱シート群 1 名のみであった.

\section{考 察}

変形性膝関節症は年間 90 万人が発症しているとの 報告もある5) 整形外科領域では診察, 治療する機会の 大変多い疾患の 1 つである. 治療としては運動療法や 薬物療法, 装具療法, サプリメント, 手術療法がある がそのなかで多用されているものに温熱療法がある. 近年の研究では局所への温熱刺激が皮膚を経由して中 枢の興奮を沈静させるという報告や ${ }^{6)}$ 局所への温熱が 非ミエリンの C 線維の活動性を増加させる7) という報 告もあり次第に神経, 血管生理が解明されつつある. また胃痛に代表される副作用を有する NSAIDs の使用 よりも温熱療法のほうが効果的であったという報告も 
散見される $。$ しかし実際の医療現場では温熱療法は 治療の時間が限られており, 治療中も器械そのものが かさばってしまうため，たとえこちらの許可があって も本人が移動することは困難である。今回われわれは 長時間使用可能で薄型で日常生活に支障をきたさない 湿熱シートを開発してその効果を検討した。

WOMAC pain では湿熱シート群, 乾熱シート群と もに効果がみられた。しかし WOMAC stiffnessでは 有意に持続して湿熱シート群で改善が認められた（図 2). Mazzuca らは膝 OA の温熱療法を WOMAC score で検討を行っている9)が stiffness についてはあまり検 討を行っていない. 他の文献も stiffness についての考 察は見当たらず比較検討はできないが湿熱シートの大 きな利点であろうと考えられる. physical function disability でも時期にずれはあるものの同様に改善が認め られている。この機序として膝関節周辺の軟部組織の 血行を改善し, 軟部組織の柔軟性向上, 疼痛を緩和し 機能改善がされているのではないかと思われる。この ことは JOA score の歩行能の改善（図 3）をみても当 てはまると思われる。乾熱と比較して湿熱のほうがよ り効果が得られやすい理由として蒸気と空気の熱伝導 の違いが挙げられる。つまり湿熱シートの熱流束は $33 \mathrm{~W} / \mathrm{m}^{2}$ であり乾熱シートの熱流束は $28 \mathrm{~W} / \mathrm{m}^{2}$ であ るので均一に的確に伝熱が行えるといえる ${ }^{10)}$ 。その結 果として筋肉, 軟部組織などの硬直・拘縮に伴う疼痛 に特に効果的であり日常生活の改善がみられたと推測 される。

今回は湿熱シートのみの調査であったが今後運動療 法などと組み合わせることにより，より効果的な結果 が期待できるのではないかと推測される.

\section{文献}

1）井澤里香, 坂本一朗, 井垣通人, 鈴木敦, 清水英史, 木田
直俊, 田邊 豊, 井関雅子, 宮崎東洋: 家庭用温熱医療機 器試験品（PCH-SS）による蒸気温熱適応の慢性腰痛 症に及ほす効果. ペインクリニック $2005 ； 26 ： 1128-$ 1132

2) Michlovitz S, Hun L, Erasala GN, Hengehold DA, Weingand KW : Continuous low-level heat wrap therapy is effective for treating wrist pain. Arch Phys Med Rehabil $2004 ; 85$ : 1409-1416

3) Moritz AR, Henriques FC : Studies in thermal injury 2. The relative importance of time and surface temperature in causation of cutaneous burns. Am J Pathol 1947 : 23 : 695

4) Bellamy N, Buchanan WW, Goldsmith CH, Campbell J, Stitt, LW : Validation study of WOMAC : a health status instrument for measuring clinically important patient relevant outcomes to antirheumatic drug therapy in patients with osteoarthritis of the hip or knee. J Rheumatol $1988 ; 15: 1833-1840$

5）川村秀哉 : 変形性膝関節症の疫学一患者数推定と患者 調查結果の検討. 整形外科と災害外科 $1995 ; \mathbf{4 4}: 12-15$

6) Mannion AF, Muntener M, Taimela S, Dvorak J : A randomized clinical trial of three active therapies for chronic low back pain. Spine $1999 ; 24$ : 2435-2448

7) Nadler SF, Steiner DJ, Erasala GN, Hengehold DA, Hinkle RT, Beth Goodale M, Abeln SB, Weingand KW : Continuous low-level heat wrap therapy provides more efficacy than Ibuprofen and acetaminophen for acute low back pain. Spine $2002 ; 27$ : 1012-1017

8) Akin M, Price W, Rodriguez G Jr, Erasala G, Hurley G, Smith RP : Continuous, low-level, topical heat wrap therapy as compared to acetaminophen for primary dysmenorrhea. J Reprod Med $2004 ; 49: 739-745$

9) Mazzuca SA, Page MC, Meldrum RD, Brandt KD, PettySaphon S : Pilot study of the effects of a heat-retaining knee sleeve on joint pain, stiffness, and function in patients with knee osteoarthritis. Arthritis Rheum 2004 ; $51: 716-721$

10) Oda H, Igaki M, Ugajin T, Suzuki A, Tsuchiya $S$, Nagashima K, Iso S, Kanosue K : Effect of warming the lower back with a heat and steam generating sheet on thermoregulatory responses and sensation. Jpn J Biometeor $2006 ; 43: 43-50$ 